\title{
Investments and economic growth in poultry farming
}

\author{
Mariana Barcho ${ }^{1, *}$, and Vasily Nechaev ${ }^{2}$ \\ ${ }^{1}$ Kuban State Agrarian University named after I. T. Trubilin, 350004, Kalinina str., 13, Krasnodar, \\ Russia \\ ${ }^{2}$ Federal Research Center of Agrarian Economy and Social Development of Rural Areas - All \\ Russian Research Institute of Agricultural Economics, 123007, Khoroshevskoye shosse, 35k2, \\ Moscow, Russia
}

\begin{abstract}
Theories of economic growth determine the leading role of investment processes. The purpose of this article is to inform the scientific community about the results of the analysis of the sectoral economic growth and investment support in the case of the poultry industry subsector. The analysis was carried out on the example of 493 organizations belonging to the type of activity 01.47 "Breeding of agricultural poultry". In the course of the study, the organizations were divided into groups according to the scale of their activities, and their financial status was analyzed, as loan debts for investment projects in the poultry farming accounted for $38 \%$. The analysis showed that the financial condition of the poultry organizations is better than the financial condition of the organizations in Russia as a whole. Also, large organizations with revenues above 2 billion rubles have better financial situation. Almost a quarter of organizations in the poultry farming are large and medium-sized ones $(23.6 \%)$. They have revenues of 800 million rubles, which allows them making the necessary investments.
\end{abstract}

\section{Introduction}

The analysis of investment and economic growth usually suggests that the economic growth is a consequence of investment. Investment theories of the economic growth determine the leading role of the investment processes and identify factors that affect the volume of investment.

In the theories of J. Keynes [1], the multiplier shows a stable dependence of the growth of the national income on the increase of investments, and the main task is the creation of additional demand in the absence of capital for the investment activity.

In the Harrod model [2], the rate of growth of the national income depends on the rate of accumulation and capital ratio (the ratio of the growth of all types of goods and the increase in output over the same period).

In the theory of economic dynamics, the growth rate of the national income increases from the increase in the volume of accumulation.

\footnotetext{
* Corresponding author: barcho_m@mail.ru
} 
In modern economic theory, economic growth is seen not simply as an increase in production, but as an increase in competitive products (works and services), which requires updating not only equipment, but also technology, and investment growth. Therefore, to increase the growth rates of production, it is necessary to improve the use of fixed assets, and structural and institutional improvement of the investment process.

\section{Materials and methods}

The purpose of the research is to analyze the sectoral economic growth and investment provision on the example of the poultry industry sub-sector.

In the course of the study, methods of comparison, graphical presentation of results, computational and constructive methods, as well as groupings were used. For the processing of statistical data, the software of the consulting financial and analytical company Akon was utilized [3].

\section{Results}

The sub-sector of poultry farming is characterized by the concentration of resources, precocity of cultivation, less feed conversion per unit of output, use of mechanized and automated technologies, and high potential for satisfying the population's food needs. All this determines the priority development of the poultry sub-sector and the availability of government programs to support it. The industry shows a stable growth (Figure 1).

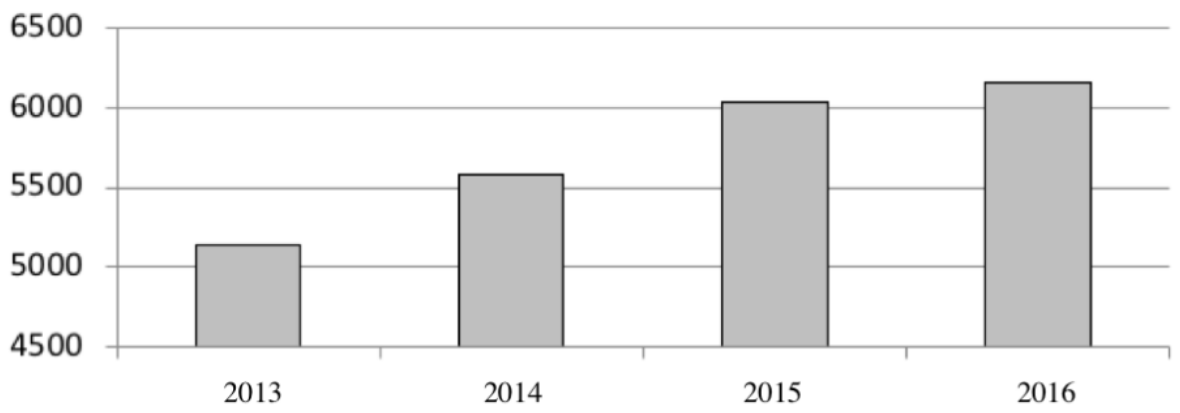

Fig. 1 Growth of the poultry production for slaughter in farms of all categories, thousand tons.

At the end of 2016 [3], the Ministry of Agriculture of the Russian Federation subsidized 3123 investment loans in the field of livestock. The largest volume of subsidized investment loans in the livestock sector was directed to the pig farming and poultry. The balance of loan debts in the poultry farming is $38 \%$.

Table 1. Structure of subsidized investment loans in the livestock sector in terms of directions

\begin{tabular}{|l|c|c|c|c|}
\hline \multicolumn{1}{|c|}{ DIrection } & $\begin{array}{c}\text { Number of } \\
\text { loans }\end{array}$ & $\begin{array}{c}\text { Amount under } \\
\text { the contract, } \\
\text { million rubles. }\end{array}$ & $\begin{array}{c}\text { The balance of loan debt as } \\
\text { of January 1, 2017, million } \\
\text { rubles. }\end{array}$ & Доля, \% \\
\hline Total & 3123 & 767820.66 & 358520.05 & 100 \\
Pib farming & 589 & 331600.89 & 161219.23 & 45 \\
Poultry & 637 & 282177.37 & 137546.78 & 38 \\
Other livestock & 538 & 70933.61 & 25206.24 & 7 \\
Technical and technological & 1077 & 51747.71 & 20650.47 & 6
\end{tabular}


modernization

Fodder production

Purchase of breeding products

Logistic centers in livestock

\begin{tabular}{c|c}
77 & 22344.93 \\
195 & 7283.17 \\
10 & 1732.98
\end{tabular}

11464.62

710.91
3

0.5

0.2

The existence of loan debts requires consideration of the financial situation of the poultry organizations. Based on the data of the official accounting statements of organizations of the Russian Federation for 2016, presented in the Rosstat database, 493 organizations were identified by the type of activity 01.47 "Breeding of agricultural poultry". Large, medium-sized, small organizations and micro-organizations are identified by the revenue share (Figure 2).

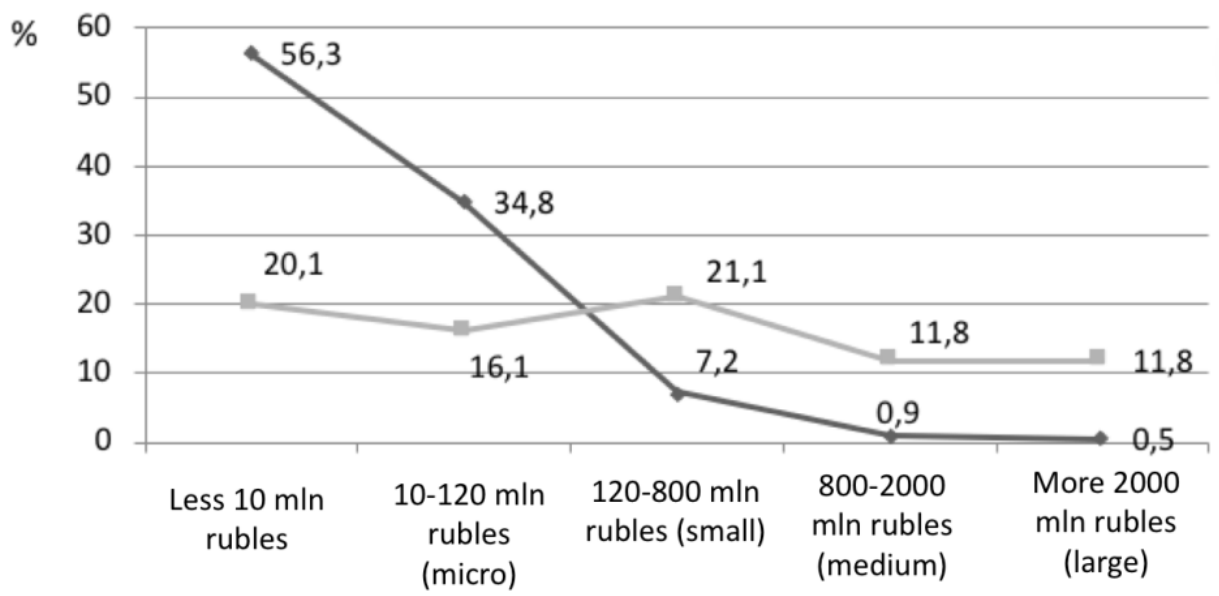

\section{$\longrightarrow$ All organizations}

- Breeding of agricultural poultry (Activity type 01.47)

Fig. 2 Comparison of organizations in Russia, including the poultry farming, in terms of revenue

In general, small, micro and smaller organizations make up $98.3 \%$ of the organizations of Russia that complicates their innovative development, since small business does not have enough funds for innovation investments. Large organizations with revenues of more than 2 billion rubles make up only $0.5 \%$. In the poultry farming, large and medium-sized organizations account for $23.6 \%$, that is, almost a quarter of organizations have revenues of 800 million rubles and more. That allows making the necessary investments. This is confirmed by the characteristics of the financial condition of the poultry organizations (Table 2).

In the presented table, the financial condition of the poultry organizations is better than the financial state of organizations in Russia as a whole. Also, large organizations have better financial state.

\section{Discussion}

The calculated financial ratios for the poultry organizations allow us drawing the following conclusions.

The coefficient of autonomy corresponds to the norm in the group of large and small poultry organizations. All other organizations demonstrate dependence on the borrowed sources of financing, especially all-Russian poultry enterprises and micro-organizations. 
The coefficient of current assets corresponds to the norm only in the group 3 for small organizations of the sector, and for all-Russian enterprises in the groups 4 and 5. This suggests that practically all organizations do not have enough funds to finance their current activities, and there are signs of insolvency (bankruptcy).

The coefficient of investment cover corresponds to the limit of 0.7 in the groups $1-3$ of the sectoral poultry organizations. In all groups of all-Russian organizations it is below the threshold values that means that not all organizations will be able to settle with creditors, since it is possible that they use short-term loans and short-term cash borrowing funds for the purchase of non-current assets (buildings, equipment, etc.).

The coefficients of current liquidity practically correspond to the industry value up to 1.5, but not lower than 1. Large and small branch organizations have the best indicators. Sectoral micro-enterprises of the $4^{\text {th }}$ group experience difficulties with the discharge of current liabilities.

The coefficient of quick liquidity corresponds to the normative values only in very small all-Russian organizations of the groups 4 and 5. In other organizations, liquid assets do not cover short-term liabilities, and there is a risk of loss of solvency.

The absolute liquidity ratio shows the ratio of the organization's liquid assets to shortterm liabilities and has very low values, which is determined by the specifics of the production cycle of the poultry organizations and characterizes the lack of liquid funds. Large organizations of the $1^{\text {st }}$ group are in a better situation.

Among the sector organizations, the efficiency of activities is the highest in the $1^{\text {st }}$ and $3^{\text {rd }}$ group. Profitability of sales shows profitability of the main activity of organizations. For the poultry organizations it is higher than all-Russian indicators. The rate of net profit reflects the efficiency of activities as a whole, since it takes into account, in addition to the profit from the sale of products (works and services), the payments on loans, exchange differences and other gains and losses. In the groups 1-3, it is higher in the poultry organizations, in the groups 4 and 5 - in all-Russian ones. Return on assets shows the return on the invested ruble in the organization's assets - for the poultry farmers it varies from 2.6 to 6.2 kopecks, for all-Russian - from 2.9 to 5.5 kopecks. We would like to note that this indicator in the poultry organizations decreases with a decrease in the size of organizations, and for all-Russian organizations it increases with a decrease in size.

\section{Conclusion}

The analysis of economic growth and investment support of the poultry organizations showed that the industry demonstrates growth in production and is provided with subsidized investment loans. The analysis of the financial status of the poultry organizations by groups, depending on the scale of their activities, indicated that the financial condition of the poultry organizations is better than the financial condition of organizations in Russia as a whole. Also, large organizations have better financial situation. In the poultry farming, large and medium-sized organizations account for $23.6 \%$, that is almost a quarter of organizations have revenues of 800 million rubles. That allows making the necessary investments. 
Table 2. Comparative indicators of the financial state of organizations by the type of activity 01.47 "Breeding of agricultural poultry" depending on the scale of activity.

\begin{tabular}{|c|c|c|c|c|c|c|c|c|c|c|}
\hline \multirow{2}{*}{ Indicators } & \multicolumn{2}{|c|}{$\begin{array}{c}\text { Group } 1 \text { - large } \\
\text { enterprises }\end{array}$} & \multicolumn{2}{|c|}{$\begin{array}{c}\text { Group } 2 \text { - medium-sized } \\
\text { enterprises }\end{array}$} & \multicolumn{2}{|c|}{$\begin{array}{c}\text { Group } 3 \text { - small } \\
\text { enterprises }\end{array}$} & \multicolumn{2}{|c|}{$\begin{array}{c}\text { Group } 4 \text { - micro- } \\
\text { enterprises }\end{array}$} & \multicolumn{2}{|c|}{$\begin{array}{c}\text { Group 5 -nano- } \\
\text { enterprise }\end{array}$} \\
\hline & Sectoral & $\begin{array}{c}\text { All- } \\
\text { Russian }\end{array}$ & Sectoral & $\begin{array}{c}\text { All- } \\
\text { Russian }\end{array}$ & Sectoral & $\begin{array}{c}\text { All- } \\
\text { Russian }\end{array}$ & Sectoral & $\begin{array}{c}\text { All- } \\
\text { Russian }\end{array}$ & Sectoral & $\begin{array}{c}\text { All- } \\
\text { Russian }\end{array}$ \\
\hline \multicolumn{11}{|l|}{ 1. Financial stability } \\
\hline $\begin{array}{l}\text { 1.1. The coefficient of } \\
\text { autonomy (financial } \\
\text { independence) }\end{array}$ & 0.5 & 0.2 & 0.3 & 0.1 & 0.5 & 0.1 & 0.2 & 0.2 & 0.3 & 0.3 \\
\hline $\begin{array}{l}\text { 1.2. Coefficient of current } \\
\text { assets }\end{array}$ & -0.03 & 0.04 & -0.2 & 0.04 & 0.2 & 0.04 & -0.06 & 0.1 & 0.03 & 0.2 \\
\hline $\begin{array}{l}\text { 1.3. Coefficient of } \\
\text { investment cover }\end{array}$ & 0.7 & 0.4 & 0.7 & 0.3 & 0.7 & 0.2 & 0.5 & 0.3 & 0.5 & 0.4 \\
\hline \multicolumn{11}{|l|}{ 2. Solvency } \\
\hline $\begin{array}{l}\text { 2.1. Coefficient of current } \\
\text { liquidity }\end{array}$ & 1.4 & 1.2 & 1.2 & 1.2 & 1.8 & 1.1 & 1.1 & 1.3 & 1.2 & 1.5 \\
\hline $\begin{array}{l}\text { 2.2. Coefficient of quick } \\
\text { liquidity }\end{array}$ & 0.7 & 0.9 & 0.4 & 0.9 & 0.6 & 0.9 & 0.5 & 1 & 0.7 & 1.1 \\
\hline $\begin{array}{l}\text { 2.3. Absolute liquidity } \\
\text { ratio }\end{array}$ & 0.08 & 0.1 & 0.03 & 0.08 & 0.04 & 0.05 & 0.02 & 0.09 & 0.03 & 0.1 \\
\hline \multicolumn{11}{|l|}{ 3. Efficiency of activities } \\
\hline $\begin{array}{l}\text { 3.1. Profitability of sales, } \\
\%\end{array}$ & 7.1 & 3.6 & 4.2 & 2.4 & 7.4 & 1.5 & 2.5 & 3.1 & 5.4 & 5.8 \\
\hline 3.2. Rate of net profit, $\%$ & 5.4 & 1.5 & 3.6 & 0.9 & 4.2 & 0.7 & 1.1 & 1.6 & 2.9 & 2.7 \\
\hline 3.3. Return on assets, $\%$ & 6.2 & 3.6 & 3.7 & 3.1 & 4.6 & 2.9 & 2.6 & 5.5 & 3.1 & 5.3 \\
\hline
\end{tabular}




\section{References}

1. J. Keynes, General theory of employment, interest and money (Macmillan Cambridge University Press, Cambridge, 1936)

2. R. F. Harrod, Economic Journal, 49 (1939)

3. TestFirm, Comparing financial state of a firm (https://www.testfirm.ru)

4. Rosinformagrotech, National report on the progress and results of the implementation in 2016 of the State Program for the Development of Agriculture and Regulation of the Markets of Agricultural Products, Raw Materials, and Food for 2013-2020 (Rosinformagrotech, Moscow, 2017) 